\title{
Structural Inversion and Behavioural Changes as a Function of Composition in Sr-La-Al-B-Si Based Glasses
}

\author{
Prasanta Kumar Ojha ${ }^{1,2 *}$, Sangram K. Rath ${ }^{1,2}$, Tapas K. Chongdar ${ }^{1}$, Nitin M. Gokhale ${ }^{1}$, \\ Ajit R. Kulkarni ${ }^{2}$ \\ ${ }^{1}$ Naval Materials Research Laboratory, Ambernath, Thane, Maharashtra, India; ${ }^{2}$ Indian Institute of Technology Bombay, Mumbai, \\ India. \\ Email: pkojha77@yahoo.co.in
}

Received April 29 $9^{\text {th }}$ 2011; revised May 27 ${ }^{\text {th }}, 2011$; accepted June $3^{\text {rd }}, 2011$.

\begin{abstract}
A series of glass sealants for solid oxide fuel cell (SOFC) with compositions SrO (x wt\%) $\mathrm{La}_{2} \mathrm{O}_{3}\left(15\right.$ wt\%) $\mathrm{Al}_{2} \mathrm{O}_{3}(15$ $w t \%) \mathrm{B}_{2} \mathrm{O}_{3}\left(40-x\right.$ wt\%) $\mathrm{SiO}_{2}$ (30wt\%) $[x=10,15,20,25 \& 30$ ] [SLABS] have been investigated by quantitative Fourier Transform Infrared Spectroscopy (FTIR). Structural findings from FTIR reveal that with increasing substitution of $\mathrm{B}_{2} \mathrm{O}_{3}$ by $\mathrm{SrO}$, even though the $\mathrm{B}_{2} \mathrm{O}_{3} / \mathrm{SiO}_{2}$ ratio decreases, however the $\mathrm{Si}$-O-non-bridging bond content in the matrix is increasing and glass structure is getting more inverted. UV-Vis Diffused Reflectance Spectroscopy (UV-Vis-DRS) of the glass series shows that electrical band gap of glasses decreases in the series from $3.07 \mathrm{eV}$ to $2.97 \mathrm{eV}$ with increasing substitution from $x=10$ to $x=30$. Conductivities of the glass samples were measured by AC impedance spectroscopy and found to be increasing from $2.74 \times 10^{-5} \mathrm{Scm}^{-1}$ to $1.09 \times 10^{-4} \mathrm{Scm}^{-1}$ with increasing substitution from $x=10$ to $x=$ 30 .
\end{abstract}

Keywords: Glass Ceramics, Mullite Ceramics Thin Tile, Composites, Bending Strength

\section{Introduction}

Oxide glasses are amorphous materials showing glass transition behavior and exhibit composition dependent properties. Basic studies of glasses reveal that the oxides used to synthesize glasses can be broadly divided into three groups. Network formers provide the basic network of glass, intermediate oxides which, though not able to form the network by themselves, participate with network formers in the basic structure, and modifier oxides "invert" the network structure by breaking the network bonds and generate non bridging oxygens. The term "invert” was introduced by Trapp and Stevels [1], because the traditional network forming oxides $\mathrm{SiO}_{2}, \mathrm{~B}_{2} \mathrm{O}_{3}$, and $\mathrm{P}_{2} \mathrm{O}_{5}$ form continuous molecular/ionic networks in normal conditions; however when the network modifying oxides are in majority on the molar basis, the glasses are inverted structurally compared to conventional glasses as shown in Figure 1. Composition of the glass and type of additives decide the nature of different structural units present in the glass which in turn decides the physicalchemical properties of glasses. For example, systematic substitution of $\mathrm{PbO}$ by $\mathrm{B}_{2} \mathrm{O}_{3}$ in ternary lead borosilicate glasses [2] decreases the thermal expansion coefficient, and increases the glass transition temperature. This has been attributed to the formation of Si-O-B linkages and increase in concentration of $\mathrm{Q}^{4}$ structural units of silicon (where $\mathrm{Q}^{\mathrm{n}}$ represents silicon structural units having n-number of bridging oxygen atoms). Substitution of $\mathrm{PbO}$ by $\mathrm{Bi}_{2} \mathrm{O}_{3}$ in $\mathrm{PbO}-\mathrm{B}_{2} \mathrm{O}_{3}-\mathrm{SiO}_{2}$ glasses results in the

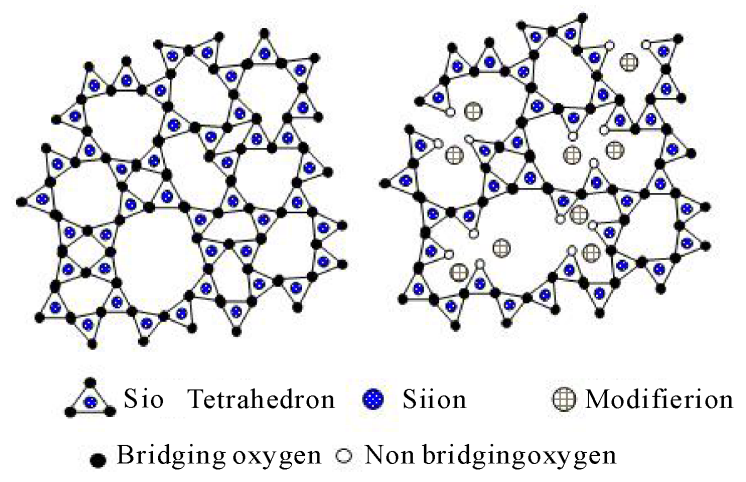

Figure 1. Structure of glass inverted by modifier ions. 
increase of thermal expansion coefficient, deformation and flow temperature [3] due to structural modification. It has been reported [4-7] that addition of network modifiers (alkali/alkaline earth metal oxides) to borosilicate glasses results in the initial conversion of $\mathrm{BO}_{3}$ to $\mathrm{BO}_{4}$ structural units. At higher concentration of modifiers, $\mathrm{BO}_{4}$ structural units in the glass are replaced by $\mathrm{BO}_{3}$-structural units (planar $\mathrm{BO}_{3}$ structural units with one non bridging oxygen atom). Hence the properties of glasses with different modifier concentrations are different. To understand the criticality of glass science it is pertinent to investigate the structure of glasses and correlate the structure with glass behavior. In this regard many researchers have tried to elucidate the structure of glasses using various spectroscopic techniques [8-21]. Extensive studies have been reported on the structural aspects of boroaluminosilicate glasses using techniques like FTIR, Raman and Magic Angle Spinning-Nuclear Magnetic Resonance (MAS-NMR) spectroscopy [11, 22-24]. These studies highlight the existence of various structural units like trigonally coordinated boron $\left(\mathrm{BO}_{3}\right)$, tetrahedrally coordinated boron $\left(\mathrm{BO}_{4}\right)$, silicon atoms with 3 and 4 bridging oxygen atoms, $\mathrm{Q}^{\mathrm{n}}$ units with Si-O-B/ Si-O-Al linkages, etc. in the glass matrix. These structural units finally govern the properties of the glasses.

In this work structure property correlation of a series of glasses with composition $\mathrm{SrO}\left(\mathrm{x}\right.$ wt\%), $\mathrm{La}_{2} \mathrm{O}_{3}(15 \mathrm{wt}$ $\%), \mathrm{Al}_{2} \mathrm{O}_{3}(15 \mathrm{wt} \%), \mathrm{B}_{2} \mathrm{O}_{3}\left(40-\mathrm{x}\right.$ wt\%) and $\mathrm{SiO}_{2}$ (30 wt $\%)$ have been investigated. Glass compositions were selected for their application as sealant in solid oxide fuel cell (SOFC) with $\mathrm{B}_{2} \mathrm{O}_{3}$ and $\mathrm{SiO}_{2}$ as the network formers, $\mathrm{Al}_{2} \mathrm{O}_{3}$ as the intermediate oxide and $\mathrm{La}_{2} \mathrm{O}_{3}$ and $\mathrm{SrO}$ as the modifier oxides. In the glass composition, concentration of $\mathrm{SiO}_{2}, \mathrm{La}_{2} \mathrm{O}_{3}$ and $\mathrm{Al}_{2} \mathrm{O}_{3}$ were kept constant and a systematic substitution of $\mathrm{B}_{2} \mathrm{O}_{3}$ by $\mathrm{SrO}[\mathrm{x}=10,15,20$, $25,30]$ was introduced. This report includes the investigation of structural modification as a function of composition by quantitative FTIR and UV-Vis Diffused Reflectance Spectroscopy (UV-Vis-DRS) and correlated with the electrical conductivity of glasses measured by AC Impedance spectroscopy.

\section{Experimental}

$\mathrm{SiO}_{2}$, AR grade from S. D. Fine-Chem. Ltd., India, $\mathrm{Al}_{2} \mathrm{O}_{3}$, AR grade from $\mathrm{CDH}$, India and $\mathrm{La}_{2} \mathrm{O}_{3}$, GR grade from Loba Chemie, India were used as received for preparation of batches. Boric acid $\left(\mathrm{H}_{3} \mathrm{BO}_{3}\right)$ (AR grade) from SRL Pvt. Ltd., India was used as the source for $\mathrm{B}_{2} \mathrm{O}_{3}$ and $\mathrm{SrCO}_{3}$, extra pure grade from Loba Chemie, India was used as the source for $\mathrm{SrO}$. Batch formulations for compositions $\mathrm{SrO}$ (x wt\%), $\mathrm{La}_{2} \mathrm{O}_{3}$ (15 wt\%), $\mathrm{Al}_{2} \mathrm{O}_{3}$ (15 wt\%), $\mathrm{B}_{2} \mathrm{O}_{3}(40-\mathrm{x} w t \%)$ and $\mathrm{SiO}_{2}(30 \mathrm{wt} \%)[\mathrm{x}=10$,
$15,20,25,30]$ were calculated considering the gravimetric factors for $\mathrm{H}_{3} \mathrm{BO}_{3}$ and $\mathrm{SrCO}_{3}$. Raw materials in appropriate proportion for $50 \mathrm{~g}$ batch size were mixed thoroughly. Total mass was melted in a platinum crucible at $1450^{\circ} \mathrm{C}$ for $1 \mathrm{hr}$ and quenched in a pre heated brass mould. Glass samples were characterized by differential thermal analysis (DTA) for their thermal behaviour. Subsequen- tly glasses were annealed at temperatures close their glass transition temperatures for removal of thermal stresses from the glass matrices.

To analyze the phases of the melt quenched sample $\mathrm{X}$-ray diffractometry (XRD) was carried out using XPert MPD, PAnalytical. Diffraction studies were carried out in the range of $20^{\circ}-80^{\circ}(2 \theta)$ with step size of $0.005^{\circ}$ using $\mathrm{CuK} \alpha$ radiation. Fourier Transform Infrared Spectroscopy (FTIR) was carried out using 1600 Series FTIR of Perkin-Elmer via KBr pellet technique method. Quantitative information about the structural groups in glasses was obtained from the deconvoluted FTIR spectra. In this report FTIR data are presented in absorbance mode for ease of deconvolution. The diffused reflectance spectroscopy (DRS) of the glass samples were carried out in UV-Vis-NIR region using Perkin Elmer precisely, Lambda 35, UV/VIS Spectroscopy. In the DRS, absorbance of the sample has been plotted against energy. The onset wavelength of the optical absorbance has been considered for band gap energy calculation using the standard equation, and is presented in the unit of electron Volt (eV). Electrical conductivity of samples were measured from room temperature to $800^{\circ} \mathrm{C}$ by Impedance Spectroscopy using AUTOLAB, ECO CHEMIE, Netherlands. Samples in the form of circular disc were inserted between two platinum disks into an alumina holder and positioned (spring-loaded) inside a top loading furnace. Platinum leads attached to the platinum plates were connected to the impedance analyzer for collecting, storing and processing of data. Impedance spectra of the glasses at different temperatures were recorded in the frequency range $100 \mathrm{~Hz}$ to $1 \mathrm{MHz}$. From the impedance data resistance of the sample was used for calculating the conductivity, taking into account the sample dimensions.

\section{Results and Discussion}

Different batch compositions used to prepare the glasses and the code for each such composition is enlisted in Table 1. $50 \mathrm{~g}$ of glass was prepared for each composition by melt quenching the batch under the conditions mentioned earlier. For phase analysis the melt quench sam-ples werAe analyzed by XRD. Figure 2 shows a representative XRD plot of the melt quenched glass with composition SLBS-4. XRD plots of all samples show absence of high intensity peaks with a broad hump ap- 
Table 1. Batches with $\mathrm{SrO}-\mathrm{La}_{2} \mathrm{O}_{3}-\mathrm{Al}_{2} \mathrm{O}_{3}-\mathrm{B}_{2} \mathrm{O}_{3}-\mathrm{SiO}_{2}$ compositions for glass making and their corresponding nomenclature.

\begin{tabular}{lccccc}
\hline \multirow{2}{*}{ Glass Code } & \multicolumn{5}{c}{ Glass Composition (wt\%) } \\
\cline { 2 - 6 } & $\mathrm{SrO}$ & $\mathrm{La}_{2} \mathrm{O}_{3}$ & $\mathrm{Al}_{2} \mathrm{O}_{3}$ & $\mathrm{~B}_{2} \mathrm{O}_{3}$ & $\mathrm{SiO}_{2}$ \\
\hline SLABS-3 & 10 & 15 & 15 & 30 & 30 \\
SLABS-4 & 15 & 15 & 15 & 25 & 30 \\
SLABS-5 & 20 & 15 & 15 & 20 & 30 \\
SLABS-6 & 25 & 15 & 15 & 15 & 30 \\
SLABS-7 & 30 & 15 & 15 & 10 & 30 \\
\hline
\end{tabular}

pearing each case which is a clear indication of the amorphous/glassy nature of the sample. For structure elucidation all the glasses were characterized through FTIR spectroscopy. Figure 3 shows FTIR spectra for different glasses. Each spectrum shows four active infrared spectral regions. First broad peak appeared in the range $400-600 \mathrm{~cm}^{-1}$ and is assigned to the bending vibration in $\mathrm{SiO}_{4}$ network. Peak in the range of $600-850$ $\mathrm{cm}^{-1}$ is attributed to the bending vibration of borate segments. $850-1200 \mathrm{~cm}^{-1}$ segment is attributed to stretching vibration of structural groups containing $\mathrm{BO}_{4}$ tetrahedral and overlaps with $\mathrm{SiO}_{4}$ tetrahedral. These structural groups consist of $\mathrm{BO}_{3}$ and $\mathrm{BO}_{4}$ units without non-bridging oxygen (NBOs) ions. Peak in the region 1200 to $1500 \mathrm{~cm}^{-1}$ arises from B-O bond vibration of $\mathrm{BO}_{3}$ units [11,25-27]. This signifies two types of network structures in the glass: one consisting of $\mathrm{BO}_{3}$ and $\mathrm{BO}_{4}$ units and the other consisting of $\mathrm{SiO}_{4}$ unit. FTIR spectra were corrected using two- point baseline correction. The spectra were normalized to eliminate the concentration effect of the powder sample in $\mathrm{KBr}$ disc. To get quantitative information about structural groups, the spectra were deconvoluted in to Gaussian bands. Only the 400 - 1600 $\mathrm{cm}^{-1}$ range was considered for deconvolution and least square method was used to analyze the graphs. A representative plot is shown in Figure 4 which illustrates deconvolution of the FTIR spectrum of SLABS-4 glass. Data generated by deconvolution of FTIR spectra of samples include peak position, peak height, FWHM of the peak, and area under the peak. Peaks were assigned for characteristic bands and relative area under the peak was calculated with respect to the total area under all the peaks. FTIR spectra of all glass samples were deconvoluted and the generated data were analysed for structural findings. Table 2 is a representative table enlisting deconvoluted data generated from FTIR spectra of SLABS-3 glass. As glasses are having complicated structures, several peaks obtained on deconvolution of FTIR spectra could not be assigned for characteristic vibrations as shown in the Table 2 . The table includes relative area under peak which gives a quantitative idea of the corresponding structural group in the glass structure. Although these glasses are having three network formers $\mathrm{BO}_{3}, \mathrm{BO}_{4}$ and $\mathrm{SiO}_{4}$ units, however, glass compositions are changing with respect to wt $\%$ of $\mathrm{B}_{2} \mathrm{O}_{3}$ in the glass matrix $\left(\mathrm{B}_{2} \mathrm{O}_{3}\right.$ is decreasing from $30 \mathrm{wt} \%$ to $10 \mathrm{wt} \%$ from SLABS-3 to SLABS-7) so it will not be technically proper to compare characteristic peaks due to $\mathrm{BO}_{3}$ and $\mathrm{BO}_{4}$ in different glasses. Therefore the effect of increasing $\mathrm{SrO}$ content as network modifier is compared in different glasses relating to the changes in SiO4 network structure. From deconvolution data the relative area under $\mathrm{Si}-\mathrm{O}^{-}$non bridging oxygen peak $\left(\sim 929 \mathrm{~cm}^{-1}\right)$ [12] was calculated for different glass compositions. A graphical presentation of the non bridging oxygen (NBO) content in the glass with respect to $\mathrm{SrO}$ content is shown in Figure 5. The relative area which is a representation of the NBO content in the glass matrix was found to increase linearly with increase in $\mathrm{SrO}$ content. This is due to $\mathrm{SrO}$ being a network modifier; it tends to invert the structure by breaking the network bonds in $\mathrm{SiO}_{4}$ tetrahedral. In the broken network, the $\mathrm{Sr}^{+2}$ ions occupy interstitial positions surrounded by non bridging oxygen ions. Lu et al. [28] reported, increase in glass network connectivity with decreasing $\mathrm{B}_{2} \mathrm{O}_{3} / \mathrm{SiO}_{2}$ in SLABS glass system. However, in this case it was observed that even if the ratio decreases from 1 (SLABS-3) to 0.333 (SLABS-7), the connectivity decreases with formation of more non bridging oxygens as the SrO content increased. This may be due to network modifiers having more impact over the glass formers such as $\mathrm{SiO}_{2}$ and $\mathrm{B}_{2} \mathrm{O}_{3}$ [29].

Diffused Reflectance Spectroscopy (DRS) of glass samples were carried out in the UV-Vis region. Figure 6 shows absorbance of glass samples in the wavelength range of 200 to $800 \mathrm{~nm}$. From the plot it is observed that with decrease in wavelength (i.e. with increase in energy) glass samples start absorbing radiation below a certain wavelength. Absorbance increases with a different gradient with increase in energy and remain constant at higher energies. This signifies an indirect type of band edge in the glasses. Wavelength of the onset point of absorbance was used to calculate the band gap of glass and the plot of band gap with respect to $\mathrm{SrO}$ content in the glass matrix is shown inset of Figure 6. The band gaps of glasses were calculated from the absorption wavelength, using the standard wavelength energy conversion formula and values found to be within 2.97 - 3.07 $\mathrm{eV}$. The band gap decreased with increase in $\mathrm{SrO}$ content in the glass. Generally, the optical absorption of glasses in the UV-Vis region is determined by the oxygen bond strength in the glass forming network. Any change in the status of the oxygen bonding, for instance, formation of non bridging oxygen (NBO) changes the characteristic absorption edge. In the present study, the position of the fundamental absorption edge shifts to higher wavelength 


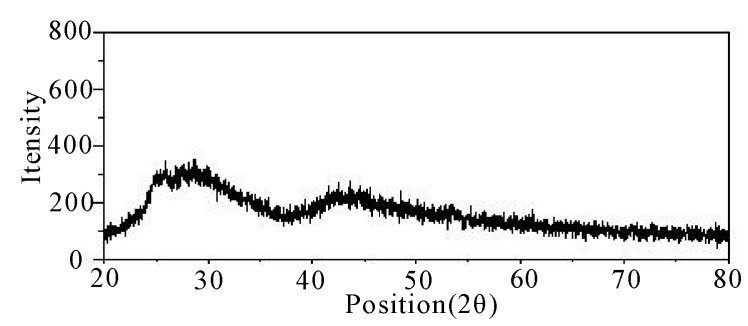

Figure 2. XRD plot of SLABS-4.

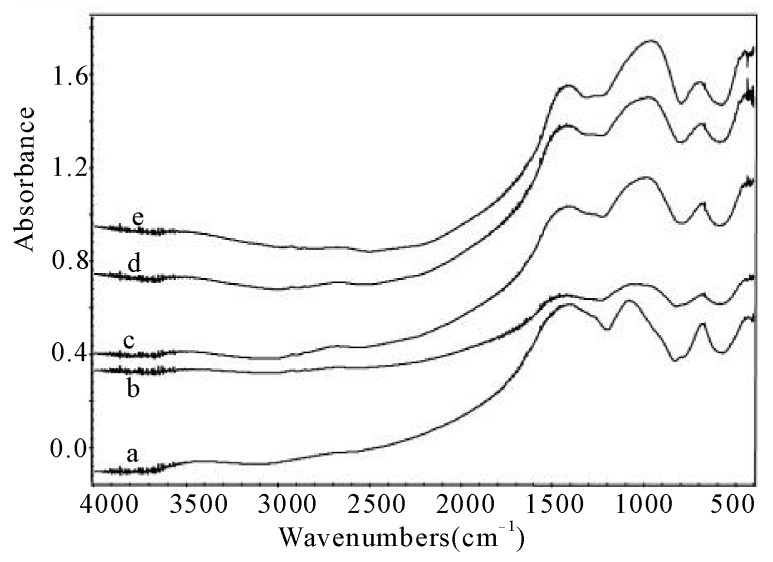

Figure 3. FTIR plots of SLABS glasses (a. SLABS-3, b. SLABS-4, c. SLABS-5, d. SLABS-6, e. SLABS-7).

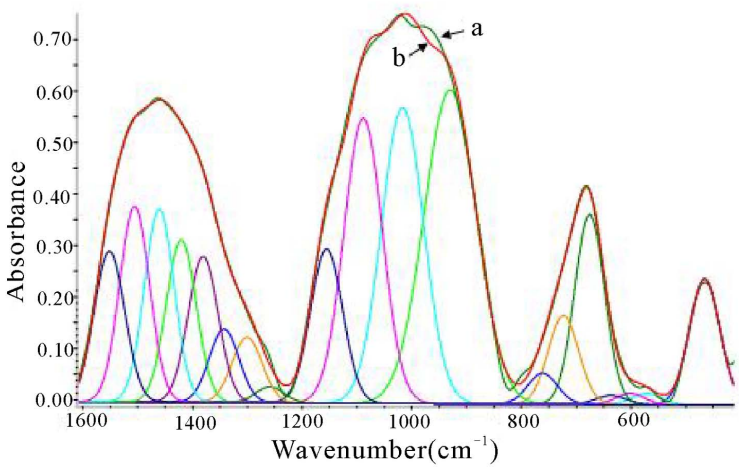

Figure 4. A typical deconvolution spectra of SLABS-4 glass a. experimental curve, b. simulated curve and the computed Gaussian bands.

(lower energy) with increasing SrO content. The shifts of the absorption band to longer wavelength correspond to the structural modification with generation of more NBOs which bound an excited electron less tightly than the bridging oxygen [30]. UV-Vis DRS result supports the findings in FTIR deconvolution study.

All the glasses have been characterized for their thermal behaviour and these glasses show glass transitions within temperature range of $554^{\circ} \mathrm{C}$ to $659^{\circ} \mathrm{C}$ and dila

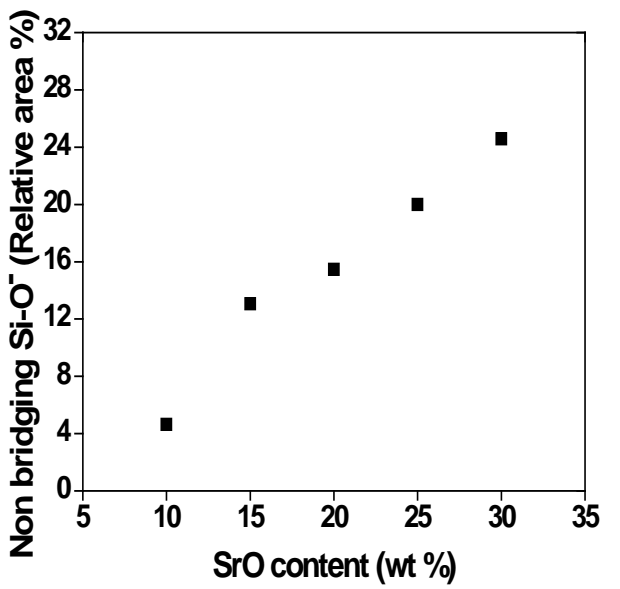

Figure 5. Non bridging $\mathrm{Si}^{-} \mathrm{O}^{-}$content in SLABS glasses as a function of SrO content.

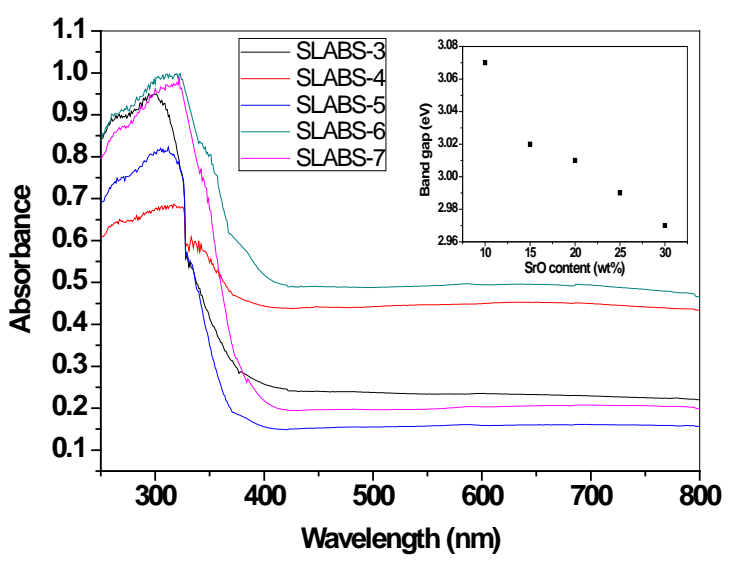

Figure 6. UV-Vis Diffused Reflectance Spectroscopy (UVVis-DRS) of glasses with band gap versus composition shown inset.

tometric softening point within $660^{\circ} \mathrm{C}$ to $709^{\circ} \mathrm{C}$. More over, both glass transition temperatures and dilatometric softening point temperatures show an increasing trend with increase in substitution in the series. In this work to elucidate a structure property correlation in the series, electrical conductivity of the glasses were investigated by AC impedance spectroscopy from room temperature to $800^{\circ} \mathrm{C}$ and conductivity of the samples were calculated from the resistance value considering the sample dimensions. As the glasses were originally designed for application in solid oxide fuel cell (SOFC) sealant so their conductivity at SOFC operational temperature which is higher than the glass transition temperatures is of great concern. Therefore, a plot of conductivity of glass samples at $800^{\circ} \mathrm{C}$ against the $\mathrm{SrO}$ content in the sample is shown in Figure 7. It is observed that conductivity of the glass samples increased from $2.74 \times 10^{-5} \mathrm{Scm}^{-1}$ to $1.09 \times$ $10^{-4} \mathrm{Scm}^{-1}$ with increase in SrO content in the glass ma- 
Table 2. Deconvolution data of the FTIR spectra of SLABS-3.

\begin{tabular}{|c|c|c|c|c|c|c|c|}
\hline Peak & Peak Type & $\begin{array}{c}\text { Peak Position } \\
\left(\mathrm{cm}^{-1}\right)\end{array}$ & Height & FWHH & Area & $\begin{array}{c}\text { Relative Area } \\
(\%)\end{array}$ & Band Assignment \\
\hline 1 & Gaussian & 431 & 0.02 & 42.89 & 0.78 & 0.76 & \\
\hline 2 & Gaussian & 453 & 0.03 & 45.56 & 1.24 & 1.20 & Si-O-Si and O-Si-O bending vib \\
\hline 3 & Gaussian & 470 & 0.01 & 37.61 & 0.59 & 0.57 & \\
\hline 4 & Gaussian & 494 & 0.01 & 40.80 & 0.54 & 0.53 & \\
\hline 5 & Gaussian & 556 & 0.00 & 37.98 & 0.01 & 0.01 & \\
\hline 6 & Gaussian & 683 & 0.13 & 78.27 & 10.55 & 10.28 & Stretching vib of B-O-B \\
\hline 7 & Gaussian & 803 & 0.00 & 36.85 & 0.03 & 0.03 & \\
\hline 8 & Gaussian & 903 & 0.07 & 66.05 & 4.76 & 4.64 & Non bridging Si-O \\
\hline 9 & Gaussian & 968 & 0.09 & 68.05 & 6.76 & 6.58 & $\mathrm{BO}_{4}$ stretching vib \\
\hline 10 & Gaussian & 1028 & 0.14 & 67.88 & 9.83 & 9.58 & \\
\hline 11 & Gaussian & 1090 & 0.15 & 69.19 & 10.98 & 10.70 & Si-O-Si antisym stretching vib \\
\hline 12 & Gaussian & 1143 & 0.06 & 51.15 & 3.15 & 3.07 & \\
\hline 13 & Gaussian & 1276 & 0.08 & 81.89 & 6.63 & 6.46 & \\
\hline 14 & Gaussian & 1370 & 0.15 & 106.99 & 16.76 & 16.33 & \\
\hline 15 & Gaussian & 1458 & 0.15 & 96.57 & 15.49 & 15.10 & B-O bond vibration of borate group \\
\hline 16 & Gaussian & 1542 & 0.13 & 90.62 & 12.16 & 11.85 & \\
\hline 17 & Gaussian & 1621 & 0.03 & 61.07 & 2.36 & 2.30 & \\
\hline
\end{tabular}

trix from $10 \mathrm{wt} \%$ to $30 \mathrm{wt} \%$. In general, conductivity in oxide glass matrix depends on two factors, temperature and number of available charge carriers (i.e. oxide ions) [31]. In this case all the conductivities are reported at a constant temperature of $800^{\circ} \mathrm{C}$, thus the temperature effect is constant for all the glasses. Again, the $\mathrm{B}_{2} \mathrm{O}_{3}$ content in the glass matrices which may be contributing to the total conductivity of the glasses is changing. So in this case the changing conductivity of glasses is correlated with the structural changes of $\mathrm{SiO}_{4}$ units only. Increasing $\mathrm{SrO}$ content in the glass leads to increase in NBO content due to structural inversion and decreasing

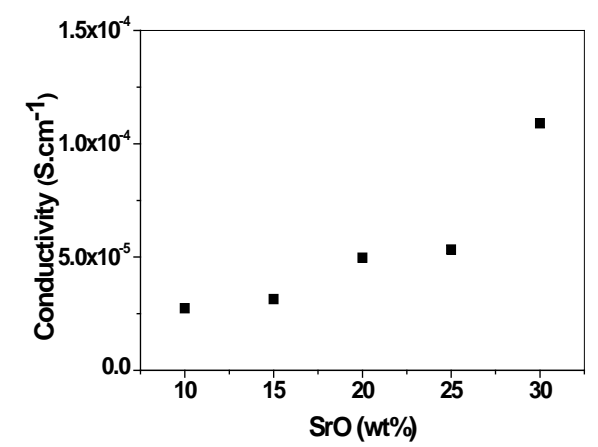

Figure 7. Conductivity of SLABS glasses versus SrO content in the glass. band edge. This makes more carriers available in the $\mathrm{SrO}$ content the conductivity of the glass increases.

\section{Conclusions}

Glasses with composition $\mathrm{SrO}\left(x\right.$ wt\%) $\mathrm{La}_{2} \mathrm{O}_{3}$ (15 wt\%) $\mathrm{Al}_{2} \mathrm{O}_{3}$ (15 wt\%) $\mathrm{B}_{2} \mathrm{O}_{3}$ (40- $x$ wt\%) $\mathrm{SiO}_{2}$ (30 wt\%) were prepared for $\mathrm{x}=10,15,20,25$ and 30. FTIR analysis show two types of network structures in the glass: one consisting of $\mathrm{BO}_{3}$ and $\mathrm{BO}_{4}$ units and the other consisting of $\mathrm{SiO}_{4}$ unit. Deconvolution of FTIR plots highlights the structural changes with composition. With increase in $\mathrm{SrO}$ content in the glass matrix, non bridging $\mathrm{Si}^{-} \mathrm{O}^{-}$content increases even though the $\mathrm{B}_{2} \mathrm{O}_{3} / \mathrm{SiO}_{2}$ decreases. This structural inversion is reflected in the properties of the glasses. The band edge of the glass samples measured by Uv-Vis DRS show a decreasing band gap with increasing $\mathrm{SrO}$ content. Conductivity of glass samples which is measured by impedance spectroscopy increases with increasing substitution of $\mathrm{B}_{2} \mathrm{O}_{3}$ by $\mathrm{SrO}$.

\section{REFERENCES}

[1] H. J. L. Trapp and J. M. Stevels, "Physical Properties of Invert Glasses,” Glasstechn. Ber., 32K V. Internationaler Glaskongress, Miinchen, 1959, pp. VI/31-52.

[2] V. Sudarsan, V. K. Shrikhande, G. P. Kothiyal and S. K. Kulshreshtha, "Structural Aspects of $\mathrm{B}_{2} \mathrm{O}_{3}$-Substituted 
$(\mathrm{PbO})_{0.5}\left(\mathrm{SiO}_{2}\right)_{0.5}$ Glasses,” Journal of Physics: Condensed Matter, Vol. 14, No. 25, 2002, pp. 6553-6565. doi:10.1088/0953-8984/14/25/322

[3] K. Kobayashi, "Thermogravimetric and MOS Capacitor Properties for PbO- $\mathrm{Bi}_{2} \mathrm{O}_{3}-\mathrm{B}_{2} \mathrm{O}_{3}-\mathrm{SiO}_{2}$ Glass System," Journal of Non-Crystalline Solids, Vol. 124, No. 2-3, 1990, pp. 229-232. doi:10.1016/0022-3093(90)90267-P

[4] G. E. Jellison and P. J. Bray, "A Structural Interpretation of $\mathrm{B}^{10}$ and $\mathrm{B}^{11}$ NMR Spectra in Sodium Borate Glasses," Journal of Non-Crystalline Solids, Vol. 29, No. 2, 1978, pp. 187-206. doi:10.1016/0022-3093(78)90113-8

[5] G. Bhasin, A. Bhatnagar, S. Bhowmick, C. Stehle, M. Affatigato, S. Feller, J. MacKenzie and S. Martin, "Short Range Order Structure in Sodium Borosilicate Glasses Obtained from Deconvolution of ${ }^{29} \mathrm{Si}$ MAS NMR Spectra," Physics and Chemistry of Glasses, Vol. 39, 1998, p. 269.

[6] B. G. Parkinson, D. Holland, M. E. Smith, A. P. Howes and C. R. Scales, "The Effect of $\mathrm{Cs}_{2} \mathrm{O}$ Additions on HLW Waste form Glasses," Journal of Non-Crystalline Solids, Vol. 351, No. 30-32, 2005, pp. 2425-2432. doi:10.1016/j.jnoncrysol.2005.06.035

[7] S. Feller, W. J. Dell and P. J. Bray, "B ${ }^{10}$ NMR Studies of Lithium Borate Glasses," Journal of Non-Crystalline Solids, Vol. 51, No. 1, 1982, pp. 21-30. doi:10.1016/0022-3093(82)90186-7

[8] R. K. Brow, D. R. Tallant, S. T. Myers and C. C. Phifer, "The Short Range Structure of Zinc Phosphate glass," Journal of Non-Crystalline Solids, Vol. 191, No. 1-2, 1995, pp. 45-55. doi:10.1016/0022-3093(95)00289-8

[9] P. P. Proulx, G. Cormier, J. A. Capobianco, B. Champagnon and M. Bettinelli, "Raman and Low Frequency Raman Spectroscopy of Lead, Zinc and Barium Metaphosphate Glasses Doped with $\mathrm{Eu}^{3+}$ Ions," Journal of Physics: Condensed Matter, Vol. 6, No. 1, 1994, pp. 275-283. doi:10.1088/0953-8984/6/1/027

[10] S. Bale and S. Rahman, "Glass Structure and Transport Properties of $\mathrm{Li}_{2} \mathrm{O}$ Containing Zinc Bismuthate Glasses," Optics Materials, Vol. 31, No. 2, 2008, pp. 333-337. doi:10.1016/j.optmat.2008.05.007

[11] K. El-Egili, "Infrared Studies of $\mathrm{Na}_{2} \mathrm{O}-\mathrm{B}_{2} \mathrm{O}_{3}-\mathrm{SiO}_{2}$ and $\mathrm{Al}_{2} \mathrm{O}_{3}-\mathrm{Na}_{2} \mathrm{O}-\mathrm{B}_{2} \mathrm{O}_{3}-\mathrm{SiO}_{2}$ Glasses,” Physica B, Vol. 325, No. 1-4, 2003, pp. 340-348. doi:10.1016/S0921-4526(02)01547-8

[12] V. Kumar, A. Arora, O. P. Pandey and K. Singh, "Studies on Thermal and Structural Properties of Glasses as Sealants for Solid Oxide Fuel Cells," International Journal of Hydrogen Energy, Vol. 33, No. 1, 2008, pp. 434-438. doi:10.1016/S0921-4526(02)01547-8

[13] F. Moreau, A. Durán and F. Muñoz, "Structure and Properties of High $\mathrm{Li}_{2} \mathrm{O}$-Containing Aluminophosphate Glasses,” Journal of European Ceramic Society, Vol. 29, No. 10, 2009, pp. 1895-1902. doi:10.1016/j.jeurceramsoc.2008.12.016

[14] J. Ramkumar, V. Sudarsan, S. Chandramouleeswaran, V. K. Shrikhande, G. P. Kothiyal, P. V. Ravindran, S. K.
Kulshreshtha and T. Mukherjee, "Structural Studies on Boroaluminosilicate Glasses,” Journal of Non-Crystalline Solids, Vol. 354, No. 15-16, 2008, pp. 1591-1597. doi:10.1016/j.jnoncrysol.2007.10.005

[15] M. S. Gaafar, H. A. Afifi and M. M. Mekawy, "Structural Studies of Some Phospho-Borate Glasses Using Ultrasonic Pulse-Echo Technique, DSC and IR Spectroscopy,” Physica B: Condensed Matter, Vol. 404, No. 12-13, 2009, pp. 1668-1673. doi:10.1016/j.jnoncrysol.2007.10.005

[16] M. S. Gaafar, N. S. A. El-Aal, O. W. Gerges and G. El-Amir, "Elastic Properties and Structural Studies on Some Zinc-Borate Glasses Derived from Ultrasonic, FT-IR and X-Ray Techniques," Journal of Alloys and Compounds, Vol. 475, No. 1-2, 2009, pp. 535-542. doi:10.1016/j.jnoncrysol.2007.10.005

[17] U. Hoppe, G. Walter, R. Kranold and D. Stachel, "Structural Specifics of Phosphate Glasses Probed by Diffraction Methods: A Review," Journal of Non-Crystalline Solids, Vol. 263-264, No. 1-2, 2000, pp. 29-47. doi:10.1016/j.jnoncrysol.2007.10.005

[18] K. Suzuya, D. L. Price, C. K. Loong and S. W. Martin, "Structure of Vitreous $\mathrm{P}_{2} \mathrm{O}_{5}$ and Alkali Phosphate Glasses," Journal of Non-Crystalline Solids, Vol. 232234, 1998, pp. 650-657.

[19] A. Hayashi, M. Nakai, M. Tatsumisago, T. Minami, Y. Himei, Y. Miura and M. Katada, "Structural Investigation of $\mathrm{SnO}-\mathrm{B}_{2} \mathrm{O}_{3}$ Glasses by Solid-State NMR and X-Ray Photoelectron Spectroscopy," Journal of Non-Crystalline Solids, Vol. 306, No. 3, 2002, pp. 227-237. doi:10.1016/S0022-3093(02)01169-9

[20] N. P. Lower, J. L. McRae, H. A. Feller, A. R. Betzen, S. Kapoor, M. Affatigato and S. A. Feller, "Physical Properties of Alkaline-Earth and Alkali Borate Glasses Prepared over an Extended Range of Compositions," Journal of Non-Crystalline Solids, Vol. 293-295, 2001, pp. 669-675.

[21] R and IR Spectroscopies," Journal of Non-Crystalline Solids, Vol. 232-234, 1998, pp. 113-118. doi:10.1016/S0022-3093(98)00380-9

[22] E. I. Kamitsos, A. P. Patsis, M. A. Karakassides and G. D. Chryssikos, "Infrared Reflectance Spectra of Lithium Borate Glasses,” Journal of Non-Crystalline Solids, Vol. 126, No. 1-2, 1990, pp. 52-67. doi:10.1016/0022-3093(90)91023-K

[23] E. I. Kamitsos, M. A. Karakassides and G. D. Chryssikos, "A Vibrational Study of Lithium Borate Glasses with High $\mathrm{Li}_{2} \mathrm{O}$ Content,” Physics and Chemistry of Glasses, Vol. 28, 1987, p. 203.

[24] E. I. Kamitsos, M. A. Karakassides and G. D. Chryssikos, "Vibrational-Spectra of Magnesium-Sodium-Borate Glasses. 2. Raman and Midinfrared Investigation of the Network Structure,” Journal of Physical Chemistry, Vol. 91, No. 5, 1987, pp. 1073-1079. doi:10.1021/j100289a014

[25] K. Lu and M. K. Mahapatra, "Network Structure and Thermal Stability Study of High Temperature Seal Glass,” Journal of Applied Physics, Vol. 104, No. 7, 2008, pp. 074910-1-074910-9. doi:10.1063/1.2979323 
[26] P. Brix and L. Gaschler, "Sealing Glass for the Production of Glass-to-Metal Seals,” US Patent, US 5137849, 1992.

[27] H. A. A. Sidek, S. Rosmawati and Z. A. Talib, "Synthesis and Optical Properties of $\mathrm{ZnO}-\mathrm{TeO}_{2}$ Glass System,"
American Journal of Applied Sciences, Vol. 6, No. 8, 2009, pp. 1489-1494. doi:10.3844/ajassp.2009.1489.1494

[28] R. H. Doremus, “Glass Science,” 2nd Edition, John Wiley \& Sons Inc., New York, 1994. 